\title{
The appearance of re-cycled urea in the digestive tract of goats during the final third of a once daily feeding of a low-protein ration
}

\author{
BY Y. OBARA AND K. SHIMBAYASHI \\ National Institute of Animal Health, Yatabe, Tsukuba, Ibaraki 305, Japan
}

(Received 23 August $1979-$ Accepted 25 April 1980)

1. An experiment was carried out with goats fed on a low-protein ration to clarify the importance of the rumen and significance of saliva in the appearance of re-cycled urea in the digestive tract during the final third of a once daily feeding regimen. The isotope-dilution method with $\left[{ }^{15} \mathrm{~N}\right]$ urea and ${ }^{15} \mathrm{NH}{ }_{4} \mathrm{Cl}$ was used.

2. When the serum urea level was $58 \mathrm{mg} \mathrm{N} / 1$, the amount of urea transferred from the blood urea pool to the rumen ammonia pool was $48.6 \mathrm{mg} \mathrm{N} / \mathrm{h}$, which was estimated to be approximately $43 \%$ of the total amount of urea having appeared in the $\mathrm{NH}_{3}$ pool of the digestive tract. When the serum urea level was I06 mg $\mathrm{N} / \mathrm{l}$, the corresponding amount of $\mathrm{NH}_{3}$ was $77.7 \mathrm{mg} \mathrm{N} / \mathrm{h}$, which was estimated to be approximately $46 \%$ of this total amount.

3. The amount of saliva secreted was measured directly by the oesophageal fistula method. Salivary secretion serves as a mode of transfer of blood urea to the rumen $\mathrm{NH}_{3}$ pool. Then the ratio, salivary secretion: diffusion through the rumen wall during the final third of the cycle was calculated to be $1: 4-1: 6$.

4. In goats fed on a low-protein diet, the rumen is an important site of appearance of blood urea in the digestive tract. It was verified that the principal mode of transfer of blood urea to the rumen was the direct diffusion through the wall of the rumen.

It is known in domestic ruminants that when a nitrogen-deficient ration is ingested, urea does not pass into the urine but is transferred to the digestive tract and converted into microbial protein to be re-utilized (Schmidt-Nielsen et al. 1957; Cocimano \& Leng, 1967). The rumen has been assumed to be the principal site of appearance of re-cycled urea in the digestive tract. This assumption has been supported by the results of experiments which demonstrated that a large quantity of urea is transferred to the rumen (Juhasz, I965; Houpt \& Houpt, 1968), and by the hypothesis that rumen microbes are responsible for most of the decomposition of urea in the body (Waldo, I968). Moreover two pathways, salivary secretion and direct diffusion through the rumen wall, have been considered to be involved in the appearance of blood urea in the rumen. Juhasz (1965) and Houpt \& Houpt (I968) suggested that direct diffusion through the rumen wall was the principal pathway. Recently, Nolan \& Leng (1972) found that the amount of re-cycled urea that appeared in the rumen was approximately $20 \%$ of the total amount of re-cycled urea that appeared in the digestive tract. They suggested that the lower part of the digestive tract was an important site of decomposition of blood urea. Furthermore, they suggested that the main pathway for the appearance of urea in the rumen was not direct diffusion through the rumen wall, but salivary secretion. The latter finding was not in agreement with those of other workers.

The present investigation, using an isotope-dilution method with $\left[{ }^{15} \mathrm{~N}\right]$ urea and ${ }^{15} \mathrm{NH}_{4} \mathrm{Cl}$ and an oesophageal fistula during the final third of a once daily feeding regimen, was designed to elucidate first the significance of the rumen in the utilization of re-cycled urea in animals fed on a low-protein diet and secondly the quantitative relationship between 
salivary secretion and diffusion through the rumen wall at the time of appearance of urea in the rumen. Finally, consideration was given on urea metabolism in domestic ruminant animals.

\section{EXPERIMENTAL}

\section{Experimental animals}

Six female goats were used, of which four had oesophageal fistulas and two had rumen fistulas. They were fed on two rations (rations nos. I and 2) once daily at 16.00 hours and given water ad lib. Ration no. I contained ( $\mathrm{g} / \mathrm{kg}$ body-weight per $\mathrm{d}$ ) 0.6 digestible crude protein (DCP), II I total digestible nutrients (TDN), so that the serum urea level was approximately $50 \mathrm{mg} \mathrm{N} / \mathrm{l}$ in animals fed on this ration at the time of experiment. Ration no. 2 contained (g/kg body-weight per d) I.2 DCP, I I 3 TDN, so that the serum urea level was approximately $100 \mathrm{mg} \mathrm{N} / 1$ in animals fed on this ration at the time of experiment. The chemical composition of rations nos. I and 2 are shown in Table I. The two rations contained hay and different proportions of two low-protein feeds (A and B) details of which are shown in Table 2. Each ration was fed for 4 weeks.

Table I. Composition of rations ( $\mathrm{g} / \mathrm{kg}$ body-weight per $d)$ and chemical composition of the constituents of rations $(\mathrm{g} / \mathrm{kg})$ fed to goats

\begin{tabular}{|c|c|c|c|}
\hline \multirow{4}{*}{$\begin{array}{l}\text { Hay } \\
\text { Low-protein feed: } \\
\text { B } \\
\text { Total digestible nutrient } \\
\text { Digestible crude protein }\end{array}$} & \multirow[b]{2}{*}{$\begin{array}{r}7.5 \\
12.0 \\
-\end{array}$} & \multirow{2}{*}{\multicolumn{2}{|c|}{$\begin{array}{r}7.5 \\
6.0 \\
6.0\end{array}$}} \\
\hline & & & \\
\hline & \multirow{3}{*}{$\begin{array}{r}11 \cdot 1 \\
0.6\end{array}$} & \multirow{2}{*}{\multicolumn{2}{|c|}{$\begin{array}{r}\text { II } \cdot 3 \\
\text { I. } 2\end{array}$}} \\
\hline & & & \\
\hline & & \multicolumn{2}{|c|}{ Low-protein feed } \\
\hline & Hay & A & B \\
\hline Moisture & 151 & 151 & 110 \\
\hline Crude protein & 84 & 74 & 186 \\
\hline Crude fat & 23 & 29 & 40 \\
\hline Crude fibre & 267 & 63 & 45 \\
\hline $\mathrm{N}$-free extract & 402 & & 568 \\
\hline Crude ash & 64 & 86 & 51 \\
\hline Total digestible nutrient & 380 & 690 & 713 \\
\hline Digestible crude protein & 28 & 32 & 137 \\
\hline
\end{tabular}

Table 2. Composition $(\mathrm{g} / \mathrm{kg})$ of low-protein feeds fed to goats

A

Ingredient

$\begin{array}{lr}\text { Maize } & 189 \\ \text { Molasses } & 76 \\ \text { Sugar beet pulp } & 474 \\ \text { Maize starch } & 189 \\ \text { Soyabean oil } & 19 \\ \text { Mineral mixture* } & 38 \\ \text { Sodium bicarbonate } & 10 \\ \text { Potassium bicarbonate } & 5 \\ \text { Vitamin E supplement } \dagger & 0.6 \\ \text { Vitamin A and D mixture } \ddagger & 0.2\end{array}$

B

Ingredient

$\begin{array}{lr}\text { Soyabean meal } & 100 \\ \text { Linseed meal } & 100 \\ \text { Barley } & 250 \\ \text { Maize } & 160 \\ \text { Wheat bran } & 250 \\ \text { Rice bran } & 100 \\ \text { Calcium carbonate } & 25 \\ \text { Sodium chloride } & 10 \\ \text { Mineral mixture* } & 4 \\ \text { Vitamin A and D mixtureł } & \text { I }\end{array}$

- Consisting (mg/kg mixture): 660 iron, I32 copper, 132 cobalt, 132 magnesium, 330 manganese, 496 sulphur, 76 I calcium, 225 phosphorus, 965 sodium chloride.

$\dagger$ Containing $100 \mathrm{mg}$ of DL- $\alpha$-tocopheryl acetate/g.

† Containing $3 \mathrm{mg}$ of retinol and $50 \mu \mathrm{g}$ of cholecalciferol $/ \mathrm{g}$. 


\section{Design of experiment}

Each experiment was carried out in the period $17-24 \mathrm{~h}$ after feeding. In Expt $\mathbf{1}$, two goats with rumen fistulas were used. The animals were placed in a metabolism cage and injected with a single dose of $300 \mathrm{mg}\left[{ }^{15} \mathrm{~N}\right]$ urea (90 atom \%) into the jugular vein. Changes in the concentration of $\left[{ }^{15} \mathrm{~N}\right]$ urea in jugular blood and ${ }^{15} \mathrm{NH}_{3}$ in the rumen were examined at Io min, $0.5,1,2,3,5$ and $7 \mathrm{~h}$ after injection. After I week both goats were injected simultaneously with a single dose of $250 \mathrm{mg}{ }^{15} \mathrm{NH}_{4} \mathrm{Cl}$ (95 atom \%) and polyethylene glycol (PEG) into the rumen. Changes in the concentrations of $\left[{ }^{15} \mathrm{~N}\right]$ urea in the jugular blood and ${ }^{15} \mathrm{NH}_{3}$ in the rumen were examined at the previously-mentioned intervals after injection. Changes in the concentrations of PEG in the rumen were examined at regular intervals. For urine analysis a $7 \mathrm{~h}$ total urine sample was collected into toluene. In Expt 2 goats with oesophageal fistulas were used. Each goat was placed in a metabolism cage and the oesophageal fistula was removed for saliva collection. At the same time a single dose of $\left[{ }^{15} \mathrm{~N}\right]$ urea was injected into the jugular vein and changes in $\left[{ }^{15} \mathrm{~N}\right]$ urea in venous blood and ${ }^{15} \mathrm{NH}_{3}$ in rumen fluid were monitored. The amount of saliva secreted was measured at hourly intervals using a graduated cylinder. A $5 \mathrm{ml}$ portion of each hourly saliva sample was used for analysis and the remainder was returned to the rumen at given intervals.

\section{Chemical analysis}

Urea- $\mathrm{N}$ in serum, urine and saliva was estimated by a modified diacetyl-monoxime method (Coulombe \& Favreau, 1963). Ammonia in rumen fluid was measured by a colorimetric method (Weatherburn, 1967 ). To determine $\left[{ }^{15} \mathrm{~N}\right]$ urea in the serum, $0.5 \mathrm{ml}$ of an enzyme solution (6 mg urease (EC 3.5.1.5) dissolved in $10 \mathrm{ml} \mathrm{0.04} \mathrm{M}$-phosphate buffer, $\mathrm{pH} 7.0$ ) and $0.5 \mathrm{ml} 0.2 \mathrm{M}$-Tris buffer, $\mathrm{pH} 9.0$, were added to $2.0 \mathrm{ml}$ serum and incubated at $37^{\circ}$ for $30 \mathrm{~min}$. The enzymic product was then converted to ammonium sulphate by Seligson's method (Seligson \& Seligson, I95I) for $\left[{ }^{15} \mathrm{~N}\right]$ urea determination. To determine urea in the urine, $\mathrm{NH}_{3}-\mathrm{N}$ was removed from the urine sample using an Amberlite CGi20 resin column and subjected to the same procedures as the serum sample. ${ }^{15} \mathrm{NH}_{3}$ in rumen fluid was estimated after conversion to $\left(\mathrm{NH}_{4}\right)_{2} \mathrm{SO}_{4}$ by Seligson's method (Seligson \& Seligson, 195I). The sample was then placed in a Rittenberg's tube and treated with potassium hypobromite to liberate $\mathrm{N}_{2}$ which was introduced into an electric discharge tube under high vacuum. ${ }^{15} \mathrm{~N}$ analyser (model NIA-I; Nippon Bunko Co., Ltd Tokyo) was used for the estimation of ${ }^{15} \mathrm{~N}$. The concentration of PEG in the rumen fluid was determined by Hyden's method (Hyden, I955).

\section{Mathematical procedures}

The results of the ${ }^{15} \mathrm{~N}$ tracer experiment were obtained by mathematical treatment of experimental values using Nolan's (1974) method. For goats injected with single doses of $\left[{ }^{15} \mathrm{~N}\right]$ urea and ${ }^{15} \mathrm{NH}_{4} \mathrm{Cl}$ into the jugular vein and rumen, respectively, the time-course of changes in ${ }^{15} \mathrm{~N}$ (atom \% excess) was plotted and the straight line obtained was expressed by the following formula:

$$
E_{t}=\sum_{i=1}^{n} A_{i} e^{-m i t},
$$

where $t$ is time, $E t$ is serum $\left[{ }^{15} \mathrm{~N}\right]$ urea and ${ }^{15} \mathrm{NH}_{3}$ (atom \% excess) present in the contents of the rumen, $A$ is the section of the $E t$ axis when $t=0, m$ is the velocity constant $(/ \mathrm{t})$ of each component, $n$ is the number of exponential components, and $i$ is the exponential component.

The area under the isotope dilution curve up to time $t$ is expressed by the following formula:

$$
\mathrm{X} t=\sum_{i=1}^{n} \frac{A i}{m i}\left(1-e^{-m i t}\right) .
$$


In the present $7 \mathrm{~h}$ experiment, computer analysis revealed that each curve was represented by two exponential functions. The border between the two functions was at $3 \mathrm{~h}$ after injection. When $\left[{ }^{15} \mathrm{~N}\right]$ urea was injected into the jugular vein, therefore, $\left[{ }^{15} \mathrm{~N}\right]$ urea in the serum (primary pool) was expressed as the sum of the two exponential functions, and ${ }^{15} \mathrm{NH}_{3}$ in the rumen (secondary pool) as the difference between these functions. On the other hand, when ${ }^{15} \mathrm{NH}_{4} \mathrm{Cl}$ was injected into the rumen, rumen $\mathrm{NH}_{3}$ was expressed as the sum of two exponential functions, and the serum urea as the difference between these functions.

Calculations of pool size and irreversible loss rate with respect to the pool into which an isotope was injected were calculated from the equation for the curves by standard procedure (see Nolan, 1974). The proportion $(Q)$ of the $\mathrm{N}$ in secondary pool $(S)$ derived from a primary pool $(P)$ was given by:

$$
Q=\frac{\text { area under the enrichment curve for pool } \mathrm{S}}{\text { area under the enrichment curve for pool } \mathrm{P}} \text {. }
$$

The rates of flow of $\mathrm{N}$ ( $c$ and $d \mathrm{mg} \mathrm{N} / \mathrm{h}$ ) associated with rumen fluid $\mathrm{NH}_{3}$ and serum urea pool were obtained by a general two-pool open-compartment model as shown in Fig. I using the results of the two experiments involving injection of ${ }^{15} \mathrm{NH}_{4} \mathrm{Cl}$ into the rumen and $\left[{ }^{15} \mathrm{~N}\right]$ urea into the jugular vein (see Nolan et al. 1976).

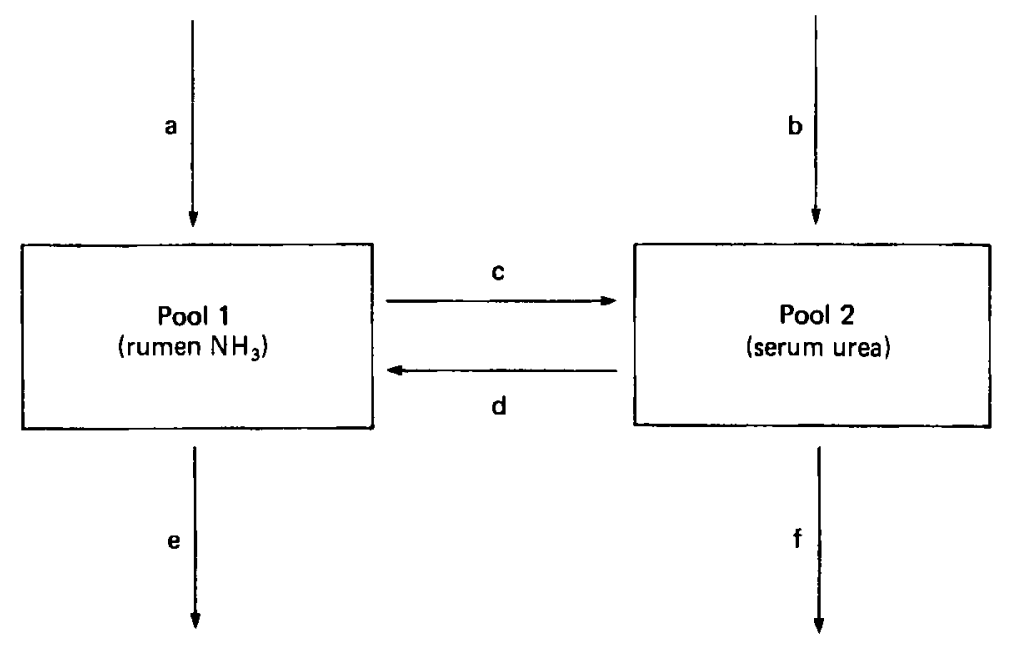

Fig. I. A general two-pool open-compartment model for nitrogen transactions associated with rumen ammonia (pool I) and serum urea (pool 2): a, b, c, d, e, f, the rates of flow of material (mg N/h).

\section{RESULTS}

Measurements of urea and ammonia metabolism during the final third of a once daily feeding regimen were determined in goats. In Expt I urea metabolism in goats injected with a single dose of $\left[{ }^{15} \mathrm{~N}\right]$ urea into the jugular vein was studied (Table 3 ). The serum urea level was in proportion to the amount of $\mathrm{N}$ ingested. The urea pool size in the body was in proportion to the serum urea level. There was no difference in the urea space between the two experimental groups, in which the urea space was approximately $50 \%$ of the body-weight. The irreversible loss of urea increased in proportion to the serum urea level. The amount of urea excreted into the urine was $194^{\circ} 0 \mathrm{mg} \mathrm{N} / \mathrm{h}$ when the serum urea level was $108 \mathrm{mg} \mathrm{N} / \mathrm{l}$. The amount of urea decreased markedly to 5.2 and $56.8 \mathrm{mg} \mathrm{N} / \mathrm{h}$ for the two goats when the serum urea level was reduced to $63 \mathrm{mg} \mathrm{N} / \mathrm{l}$. 


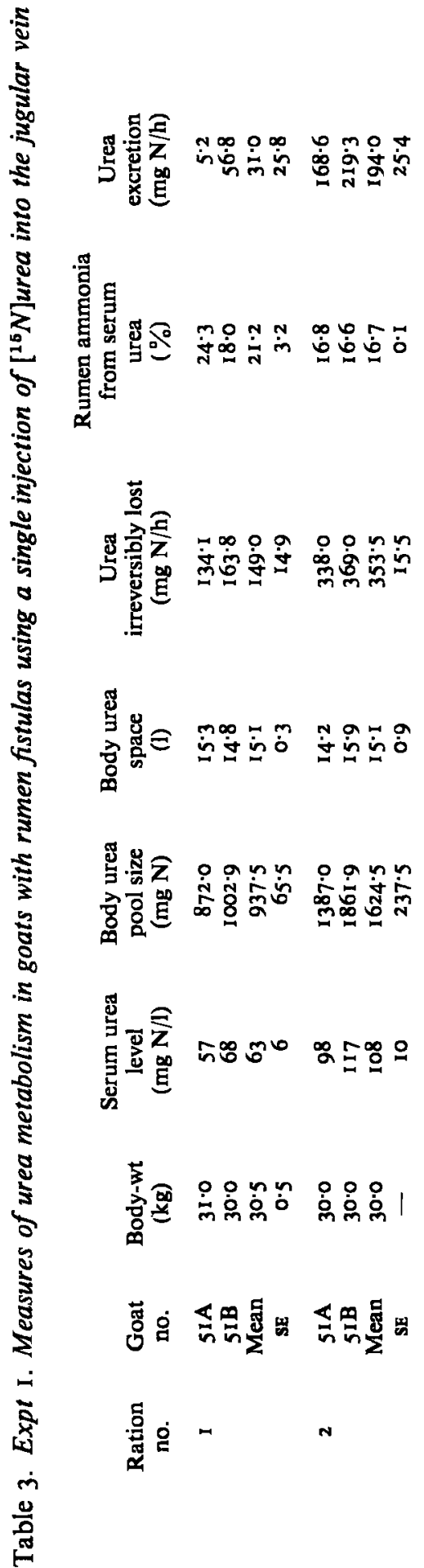




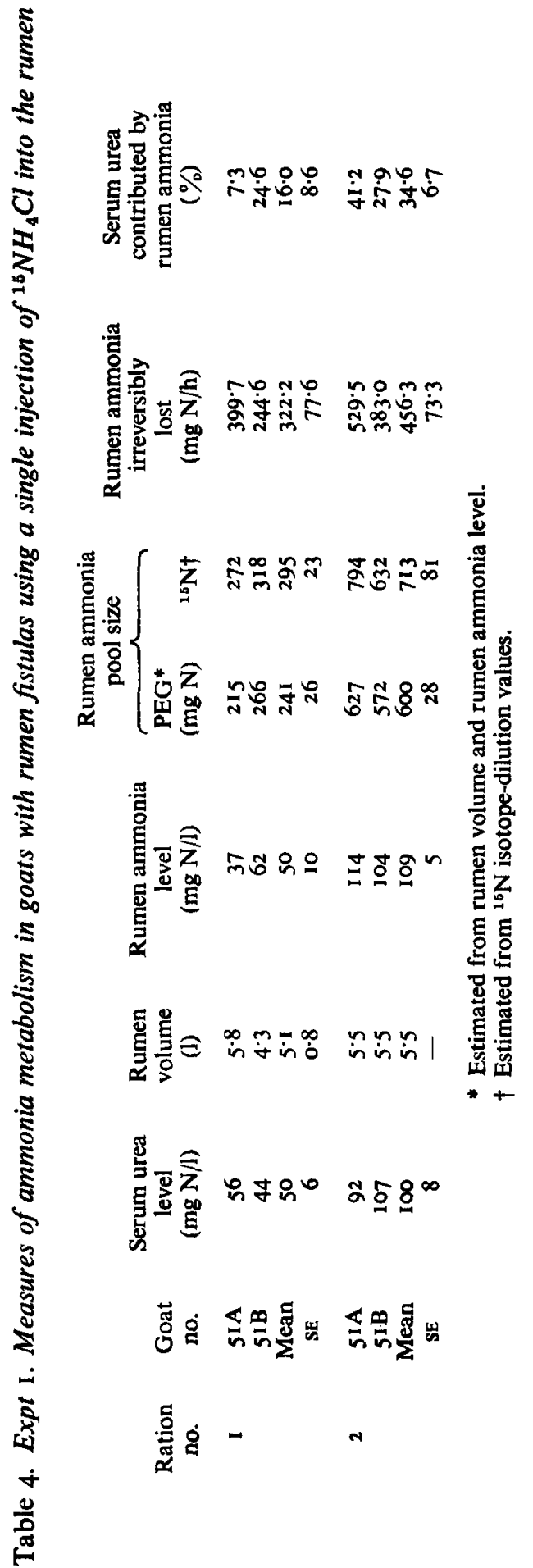




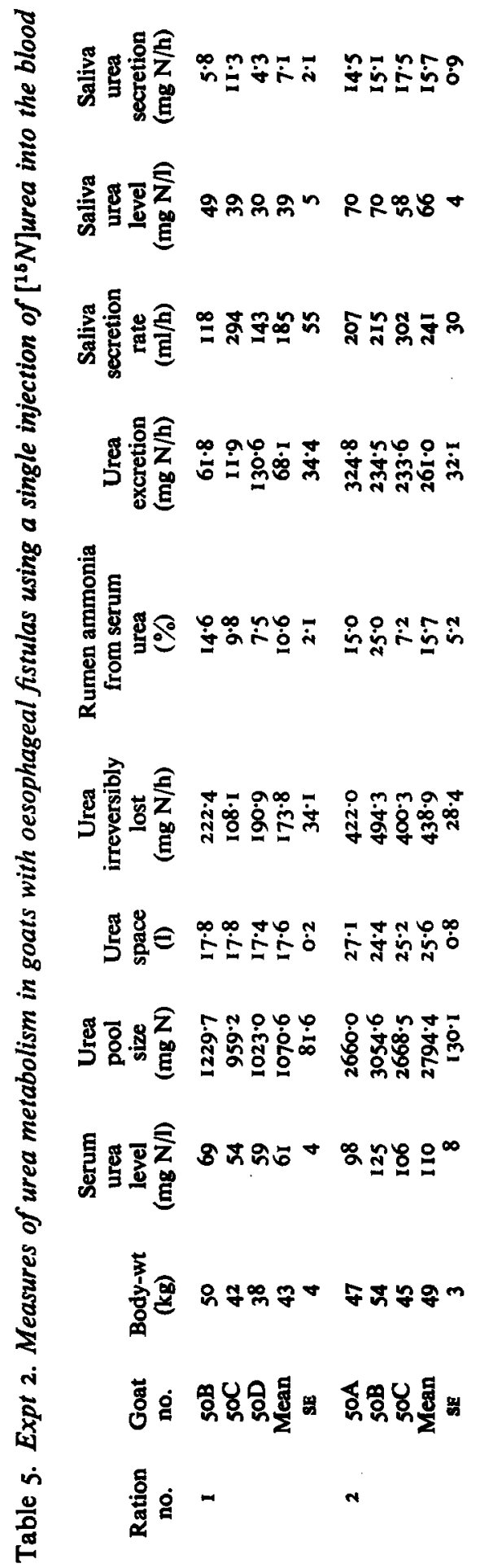


Goats were injected with a single dose of ${ }^{15} \mathrm{NH}_{4} \mathrm{Cl}$ into the rumen. Table 4 presents measurements of $\mathrm{NH}_{3}$ metabolism. The rumen $\mathrm{NH}_{3}$ levels for the two goats were 50 and I09 $\mathrm{mg} \mathrm{N} / \mathrm{l}$ and almost equal to the serum urea levels. The volume of the rumen was approximately 51 when estimated by the PEG-dilution method. The rumen $\mathrm{NH}_{3}$ pool size calculated from the rumen $\mathrm{NH}_{3}$ level and the volume of the rumen was compared with that estimated by the ${ }^{15} \mathrm{NH}_{3}$-dilution method. The rumen $\mathrm{NH}_{3}$ pool size seemed to reflect the serum urea level. There was a considerable individual difference in the irreversible $\mathrm{NH}_{3}$ loss in the rumen. However, in general, there was a relationship between the rumen $\mathrm{NH}_{3}$ loss and the serum urea level.

In Expt 2 measurements of urea metabolism were obtained for goats with oesophageal fistulas while the extent of salivary excretion was monitored (Table 5). The results showed essentially the same trend as those obtained in Expt I. The salivary urea level was $60 \%$ of the serum urea level in both experimental groups. The amount of salivary secretion was 185 and $24 \mathrm{Iml} / \mathrm{h}$ in the groups given rations nos. I and 2 respectively. There was a fairly large individual difference in the values obtained for each group. The amounts of urea discharged into the rumen via the saliva were $7 \cdot 1$ and $15.7 \mathrm{mg} \mathrm{N} / \mathrm{h}$ in the groups given rations nos. I and 2 respectively, and this was related to the serum level.

The amounts of $\mathrm{N}$ moving within the rumen, blood and lower part of the digestive tract during the final third of a once daily feeding regimen were estimated and are presented in Table 6. The values were derived from the means of the values shown in Tables 3-5. The amount of $\mathrm{N}$ transferred from the serum urea pool to the rumen $\mathrm{NH}_{3}$ pool was 48.6 and $77.7 \mathrm{mg} \mathrm{N} / \mathrm{h}$ in the groups given rations nos. I and 2 respectively. The amount of $\mathrm{N}$ transferred to the $\mathrm{NH}_{3}$ pool of the whole digestive tract was I 14.2 and $168.7 \mathrm{mg} \mathrm{N} / \mathrm{h}$ in the groups given rations nos. I and 2 respectively. The amount of blood urea transferred to the rumen $\mathrm{NH}_{3}$ pool relative to that transferred to the ammonia pool of the whole digestive tract was 42.6 and $46.1 \%$ when the serum urea levels were 58 and $106 \mathrm{mg} \mathrm{N} / 1$ respectively. On the other hand, the quantitative ratio, salivary secretion:rumen diffusion, which serves as a mode of transfer of blood urea to the rumen $\mathrm{NH}_{3}$ pool was $\mathrm{I}: 6$ and $\mathrm{I}: 4$, when the serum urea levels were 58 and $106 \mathrm{mg} \mathrm{N} / 1$ respectively. Therefore, it was demonstrated that the rate of diffusion in the rumen wall was much higher in goats given rations nos. I and 2 when the blood urea level was low.

Table 6. Estimates of the nitrogen flow

Serum urea level (mg N/l)

Rumen ammonia level ( $\mathrm{mg} \mathrm{N} / \mathrm{l}$ )

Irreversible loss of urea from serum (mg N/h) (A)

Irreversible loss of rumen $\mathrm{NH}_{3}(\mathrm{mg} \mathrm{N} / \mathrm{h})$

Rumen $\mathbf{N H}_{\mathrm{a}}$ derived from serum urea (\%)

Serum urea derived from rumen $\mathrm{NH}_{3}(\%)$

Urea excretion rate ( $\mathrm{mg} \mathrm{N} / \mathrm{h}$ ) (B)

Saliva urea secretion $(\mathrm{mg} N / \mathrm{h})(\mathrm{C})$

Rate of transfer of serum urea to rumen $\mathrm{NH}_{3}(\mathrm{mg} \mathrm{N} / \mathrm{h})(\mathrm{D})$

Rate of transfer of rumen $\mathrm{NH}_{3}$ to serum urea (mg N/h)

Rate of transfer of serum urea to whole digestive tract (mg N/h) (A-B)

Rate of transfer of serum urea to lower tract $(\mathrm{mg} \mathrm{N} / \mathrm{h})((\mathrm{A} \div \mathrm{B})-\mathrm{D})$

Rate of diffusion urea through rumen wall ( $\mathrm{mg} \mathrm{N} / \mathrm{h})(\mathrm{D}-\mathrm{C}$ )

Amount of serum urea transferred to rumen relative to that of whole

digestive tract $(\%)(\mathrm{D} \div(\mathrm{A}-\mathrm{B}) \times 100)$

Saivary secretion: rumen $(C:(D-C))$

$\begin{array}{cc}\text { Ration no. } & \text { Ration no. } \\ 58 & 106 \\ 67 & 111 \\ 163.8 & 404 \cdot 7 \\ 322 \cdot 2 & 456 \cdot 3 \\ 14 \cdot 8 & 16 \cdot 1 \\ 16 \cdot 0 & 34 \cdot 6 \\ 49 \cdot 6 & 236 \cdot 1 \\ 7 \cdot 1 & 15 \cdot 7 \\ 48 \cdot 6 & 77 \cdot 7 \\ 26.8 & 148 \cdot 3 \\ 114.2 & 168 \cdot 7 \\ 71 \cdot 3 & 91 \cdot 0 \\ 41 \cdot 5 & 62 \cdot 0 \\ & \\ 42.6 & 46.1 \\ 1: 6 & 1: 4\end{array}$




\section{DISCUSSION}

First, the authors must emphasize that the results of the present experiment were obtained during the final third of a once daily feeding regimen, and therefore cannot be considered on a $24 \mathrm{~h}$ basis. When the animals were fed once daily, the serum urea level and the rumen $\mathrm{NH}_{3}$ concentration were hardly changed during the final third of a $24 \mathrm{~h}$ cycle. Assuming that the final third of a $24 \mathrm{~h}$ cycle is in a steady-state condition, the isotope-dilution experiment was carried out for $7 \mathrm{~h}$ starting $17 \mathrm{~h}$ after feeding. However, the present experimental situation might not be considered as steady-state. If so, it is assumed that the experimental results were derived using steady-state kinetics in a non-steady-state situation. Nolan \& Leng (1972) divided the daily ration into twenty-four equal portions, which were given to sheep at hourly intervals, so that the blood urea and rumen $\mathrm{NH}_{3}$ levels might be constant throughout the experimental period. In sheep held in a steady-state, a quantitative study was made of urea metabolism.

Seven samples taken over a $7 \mathrm{~h}$ period in the present experiment might not give sufficient values to fit the exponential terms which are necessary to determine the area under the curves in the mathematical treatment. Compared with the experiments of Nolan and his co-workers (Nolan \& Leng, 1972; Nolan et al. 1976), the rate of transfer between rumen $\mathbf{N H}_{3}$ and the blood urea pool in the present experiment appeared to be estimated lower. Similarly, possible errors in the calculation of pool size and irreversible loss might be induced in the present experiment. The amount of $\mathbf{N}$ transferred could have been estimated more exactly in the experiment of Nolan \& Leng (1972), since their work involved sampling for 2-3000 min by which time the last exponent was very well defined.

As indicated in Table 5, the amounts of urea appearing in the whole digestive tract were I 14.2 and $168.7 \mathrm{mg} \mathrm{N} / \mathrm{h}$, when the serum urea levels were $5^{8}$ and $106 \mathrm{mg} \mathrm{N} / \mathrm{l}$ respectively. It was estimated that the relative transfer of urea to the rumen were 43 and $46 \%$ of the amounts of urea appearing in the whole digestive tract when the serum urea levels were 58 and $106 \mathrm{mg}$ $\mathrm{N} / \mathrm{l}$ respectively. Houpt (1959) estimated that the amount of urea- $\mathrm{N}$ transferred from the blood to the digestive tract was in the range $7.8-13.0 \mathrm{mmol} / \mathrm{h}$ (106-I $82 \mathrm{mg} \mathrm{N} / \mathrm{h}$ ). In addition, Houpt (1959) reported that when the rumen contents were removed and the rumen filled with artificial saliva, $5.2 \mathrm{mmol}$ urea- $\mathrm{N} / \mathrm{h}(73 \mathrm{mg} \mathrm{N} / \mathrm{h})$ was transferred to the rumen, and suggested the importance of this organ in urea metabolism. The latter results were obtained from an experiment conducted with animals under anaesthesia and the same results may not have been obtained with intact animals. Nolan \& Leng (1972) pointed out from the results of the isotope-dilution method during a $24 \mathrm{~h}$ cycle that the lower part of the digestive tract played a more important role than the rumen in the utilization of re-cycled urea. According to Nolan \& Leng (1972), the amount of blood urea-N transferred to the whole digestive tract was $6.3 \mathrm{~g} / \mathrm{d}(262 \mathrm{mg} \mathrm{N} / \mathrm{h})$. Of this amount, only $1 \cdot 2 \mathrm{~g} / \mathrm{d}(50 \mathrm{mg} \mathrm{N} / \mathrm{h})$ was introduced into the rumen $\mathrm{NH}_{3}$ pool. Accordingly, the rate of urea transferred into the rumen was less than $20 \%$ of that of the whole digestive tract. These results reported by Nolan \& Leng (1972) have raised controversy, since they are not in agreement with the hypothesis of Waldo (1968) that the decomposition of urea may take place in the rumen in the living body, and the result previously reported that a large amount of urea was transferred to the rumen (Houpt, 1959; Juhasz, 1965). In the present experiment with goats given low-protein rations, the rumen was confirmed to be a principal organ of the digestive tract to which re-cycled urea was transferred. It should be noted that Nolan \& Leng's (1972) result was obtained from animals in which the plasma urea level was as high as $225 \mathrm{mg} \mathrm{N} / \mathrm{l}$. On the other hand, the present authors' results were obtained from animals in which the serum urea level was 58 or $106 \mathrm{mg} \mathrm{N} / \mathrm{l}$. Furthermore, the authors estimated that the amounts of urea 
appearing in the rumen relative to those appearing in the whole digestive tract in animals given a normal-or high-protein ration were 22 and $14 \%$ when the serum urea levels were 175 and $350 \mathrm{mg} \mathrm{N} / 1$ respectively. In short, the larger the amount of $\mathrm{N}$ ingested, the lower was this relative amount (Y. Obara and $\mathrm{K}$. Shimbayashi, unpublished results). In this manner the serum urea level varied with the amount of $\mathbf{N}$ ingested. In a ruminant given a low-protein ration in which the amount of $\mathbf{N}$ ingested was so small that the serum urea level was low, re-cycled urea was presumed to be utilized in the rumen. In ruminants which had ingested a sufficient or an excessive amount of $\mathrm{N}$, the rumen was assumed to be replaced as the site of appearance of re-cycled urea by the lower part of digestive tract. However, the nutritional physiological significance of the appearance of re-cycled urea in the lower part of the digestive tract is not known.

In the present experiment, the amount of urea discharged into the rumen through saliva was actually measured in goats with an oesophageal fistula. Various methods have been reported for the collection of saliva (Hyden, 1958; Sasaki \& Umezu, 1962; Tribe \& Peel, 1963). Of these methods, the oesophageal fistula method has been regarded as the best, since it gives less stimulation to the animal at the time of collection than any other method. The salivary urea level obtained from the present experiment was almost $60 \%$ of the serum urea level and agreed with the experimental values reported by Somers (196I). The amount of saliva discharged into the rumen ranged from 118 to $302 \mathrm{ml} / \mathrm{h}$, showing the remarkable individual difference. Few experiments have been performed to measure the saliva directly in order to obtain quantitative estimates of urea metabolism. Only Houpt (1959) carried out an experiment with anaesthetized animals in which the oesophageal region had been ligatured to collect saliva. According to Houpt (1959), the amount of urea transferred to the rumen through saliva was only $6 \%$ of that of re-cycled urea appearing in this organ. In Houpt's (1959) experiment the rumen contents were removed, and it seems possible that the amount of urea diffused in the rumen may have been over-estimated. Since the present authors could actually measure the amount of urea discharged into the saliva, the quantitative relationship between the amount of the two urea fractions appearing in the rumen could be elucidated. The two fractions were the urea discharged in and transferred by the saliva to this organ, and the urea diffused in the rumen wall. In the present experiment the amount of blood urea appearing in the rumen was determined by the ${ }^{15} \mathrm{~N}$ isotope-dilution method and from this value was subtracted the amount of urea discharged into the saliva to obtain the amount of urea diffused in the rumen wall. As a result, the quantitative ratio, salivary urea secretion: urea diffusion in the rumen was approximately $1: 4-1: 6$. It was assumed that the diffusion in the rumen wall might be a principal pathway involved in the appearance of urea in the rumen. In an experiment with animals in which the serum level was 175 or 350 $\mathrm{mg} \mathrm{N} / 1$, it was estimated that more than $80 \%$ of the amount of urea appearing in the rumen might have been derived from urea discharged in saliva ( $Y$. Obara and K. Shimbayashi, unpublished results). The results mentioned previously revealed an outstanding fact; that is, the serum urea level varies with the amount of $N$ ingested, and a reverse occurs in the ratio, salivary secretion: urea diffused in the rumen. Further experiments may be necessary before the mechanism of reversion of this ratio is clarified.

As discussed previously, urea metabolism in domestic ruminants seems to vary greatly with the amount of $\mathrm{N}$ ingested and the serum urea level. Such great variation may be useful for the interpretation of the discrepancy in previously-reported experimental results. In animals given a low-protein ration, the rumen plays an important role in the utilization of re-cycled urea in the whole digestive tract. Urea may appear in the rumen chiefly by direct diffusion across the rumen wall. The amount of urea discharged in and transferred by saliva seems to contribute little to that appearing in the rumen. The transfer of intrinsic urea from the blood to the rumen may be influenced not only by the content of $\mathrm{N}$ but also by the quality 
of carbohydrate and other nutrients of food contained in the rumen at the time. An improvement in techniques seems to be required to make the rumen display its function sufficiently and to economize in the $\mathrm{N}$ content of a ration.

The authors wish to express their grateful thanks to Mr Kunio Nagatomo, of the Chuo Animal Hygiene Service Centre, Prefecture of Saga, for technical assistance.

\section{REFERENCES}

Cocimano, M. R. \& Leng, R. A. (1967). Br. J. Nutr. 21, 353.

Coulombe, J. J. \& Favreau, L. (1963). Clin. Chem. 9, 102.

Houpt, T. R. (1959). Am.J. Physiol. x97, 115.

Houpt, T. R. \& Houpt, K. A. (1968). Am. J. Physiol. 214, 1296.

Hyden, S. (1955). Kl. LandbrHogsk. Ann. 22, 139.

Hyden, S. (1958). Kl. LandbrHogsk. Ann. 24, 55.

Juhasz, B. (1965). Acta vet. Acad. Sci. hung. 15, 25.

Nolan, J. V. (1974). Proc. Nutr. Soc. 33, 1.

Nolan, J. V. \& Leng, R. A. (1972). Br. J. Nutr. $27,177$.

Nolan, J. V., Norton, B. W. \& Leng, R. A. (1976). Br. J. Nutr. 35, 127.

Sasaki, Y. \& Umezu, M. (1962). Tohoku J. agric. Res. 13, 211.

Schmidt-Nielsen, B., Schmidt-Nielsen, K., Houpt, T. R. \& Jarnum, S. A. (1957). Am. J. Physiol. 188, 477.

Seligson, D. \& Seligson, H. (1951). J. Lab. clin. Med. 38, 324.

Somers, M. ( 1961 ). Aust. J. exp. Biol. 39, I I I.

Tribe, D. E. \& Peel, L. (1963). Aust. J. Agric. Res. 14, 330.

Waldo, D. R. (1968). J. Dairy Sci. 51, 265.

Weatherburn, M. W. (1967). Analyt. Chem. 39, 971. 